\title{
ISRM Suggested Methods for Determining the Creep Characteristics of Rock
}

\author{
Ömer Aydan · Takashi Ito • Ugur Özbay • \\ M. Kwasniewski $\cdot$ K. Shariar $\cdot$ T. Okuno • \\ A. Özgenoğlu $\cdot$ D. F. Malan $\cdot$ T. Okada
}

\section{Introduction}

It is important to note that creep is only one aspect of the time-dependent behavior of rocks. In Fig. 1, three cases are illustrated with respect to the complete stress-strain curve: creep, i.e., increasing strain when the stress is held constant; stress relaxation, i.e., decreasing stress when the strain is held constant; and a combination of both, when the rock unloads along a chosen unloading path. This ISRM suggested method deals only with the case of creep, which is particularly relevant for cases where the applied load or stress is kept constant.

Creep tests have also been carried out on soft rocks such as tuff, shale, lignite, and sandstone, medium-hard rocks such

Please send any written comments on this ISRM suggested method to Prof. Resat Ulusay, President of the ISRM Commission on Testing Methods, Hacettepe University, Department of Geological Engineering, 06800 Beytepe, Ankara, Turkey.

Ö. Aydan (correspondence author)

Department of Civil Engineering and Architecture,

University of the Ryukyus, Nishihara, Okinawa, Japan

e-mail: aydan@tec.u-ryukyu.ac.jp

Ö. Aydan

Tokai University, Shizuoka, Japan

T. Ito

Department of Civil Engineering, Toyota National

College of Technology, Toyota, Japan

U. Özbay

Department of Mining Engineering, Colorado School

of Mines, Golden, CO, USA

M. Kwasniewski

Mining and Geology Faculty, Silesian University of Technology,

Gliwice, Poland as marble, limestone, and rock salt, and hard rocks such as granite and andesite (i.e., Akagi 1976; Akai et al. 1979, 1984; Ito and Akagi 2001; Berest et al. 2005; Doktan 1983; Passaris 1979; Serata et al. 1968; Wawersik 1983; Okubo et al. 1991, 1993; Masuda et al. 1987, 1988; Ishizuka et al. 1993; Lockner and Byerlee 1977; Boukharov et al. 1995; Fabre and Pellet 2006; Aydan et al. 1995; Chan 1997; Cristescu and Hunsche 1998; Hunsche 1992; Hunsche and Hampel 1999; Ito et al. 1999; Mottahed and Szeki 1982; Perzyna 1966; Slizowski and Lankof 2003; Yang et al. 1999). These experiments were mostly carried out under compressive loading conditions.

There are few studies on rocks using creep tests under a tensile loading regime (Ito and Sasajima 1980, 1987; Ito et al. 2008; Aydan et al. 2011). In particular, shallow underground openings may be subjected to a sustained tensile stress regime, which requires the creep behavior of rocks under such conditions.

\author{
K. Shariar \\ Department of Mining Engineering, Amirkabir University, \\ Tehran, Iran \\ T. Okuno \\ Shimizu Corporation, Institute of Technology, Tokyo, Japan
}

\author{
A. Özgenoğlu \\ Engineering Faculty, Atılım University, Ankara, Türkiye \\ D. F. Malan \\ Department of Mining Engineering, Pretoria University, \\ Pretoria, South Africa \\ T. Okada \\ Central Research Institute of Electrical Power Industry, \\ Abiko, Japan
}




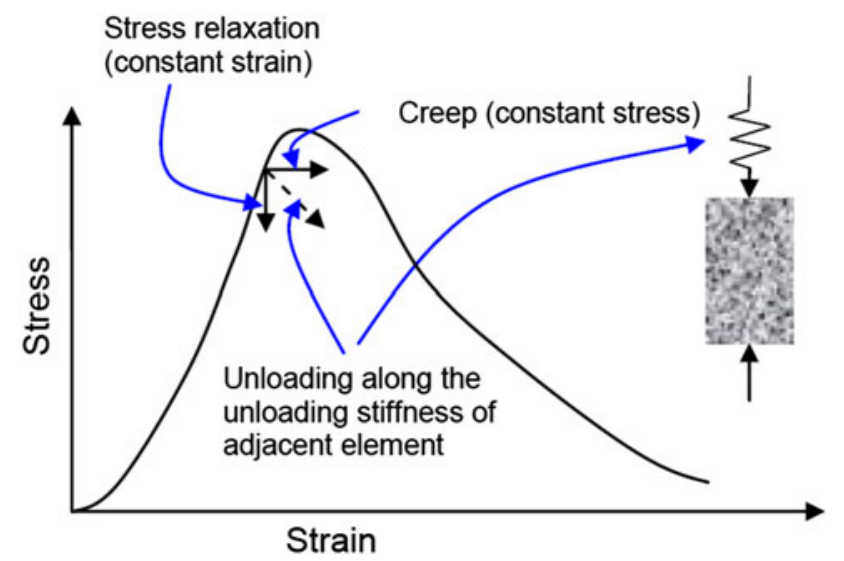

Fig. 1 Possible stress-strain paths during testing for the timedependent characteristics of rocks (from Hagros et al. 2008)

Creep experiments are often used to determine the timedependent strength and/or time-dependent deformation modulus of rocks. It has often been stated that creep of rocks does not occur unless the load/stress level exceeds a certain threshold value, which is sometimes defined as the long-term strength of rocks (Ladanyi 1974; Bieniawski 1970). Creep behavior is generally divided into primary, secondary, and tertiary, or accelerated, creep stages.

The creep characteristics of rocks are very important for assessing the long-term stability of rock engineering structures. These ISRM suggested methods have been developed for laboratory creep testing of rocks in the light of the available creep testing techniques used in rock mechanics as well as other disciplines of engineering.

\section{Scope}

The suggested methods for creep tests described herein concern the creep characteristics of intact rocks under the indirect tensile stress regime of the Brazilian test and the uniaxial and triaxial compression tests in the light of available creep testing techniques used in the field of rock mechanics as well as other disciplines of engineering under laboratory conditions. Three separate methods have been included because the reader may wish to establish the creep behavior in tension, uniaxial compression or triaxial compression.

\section{Apparatuses}

Apparatuses for creep tests can be of the cantilever type or the load/displacement-controlled type. Although the details of each testing machine may differ, the required features of apparatuses for creep tests are described in this section. (a)

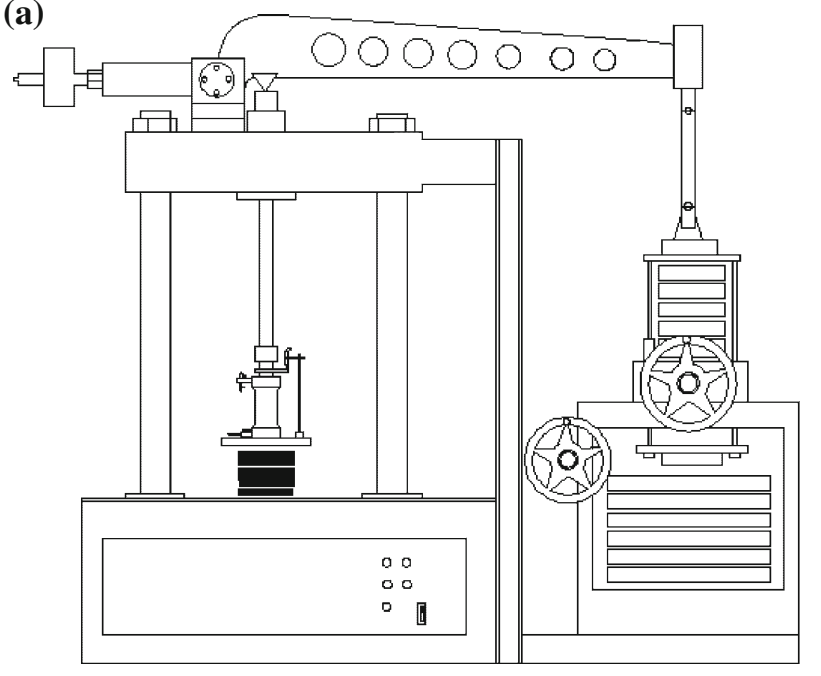

(b)

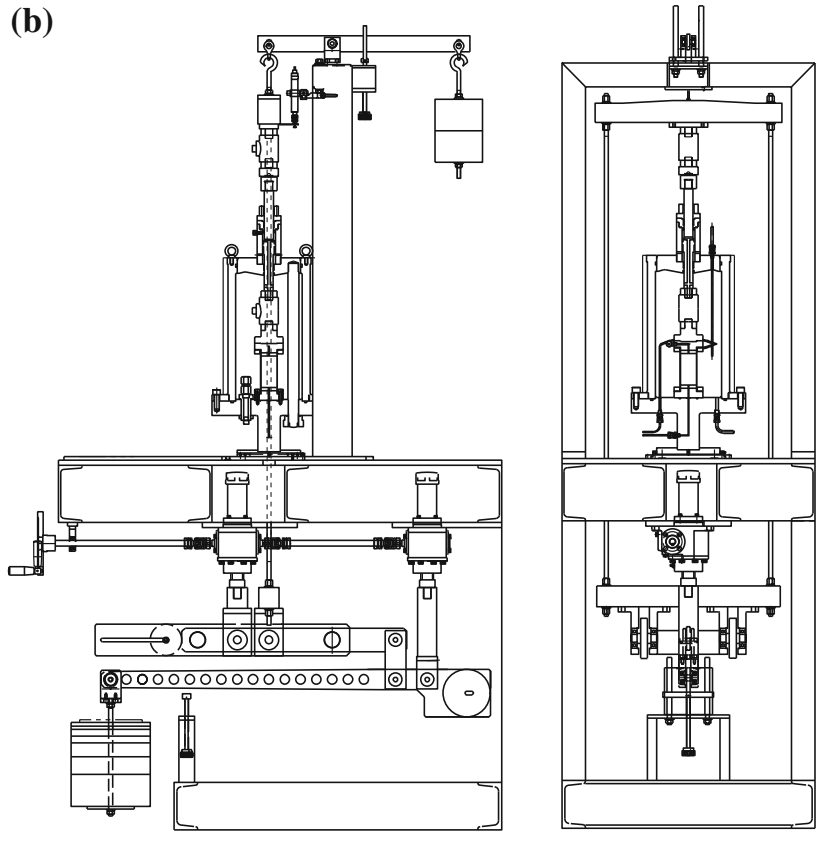

Fig. 2 Examples of cantilever-type creep apparatuses: a single-arm cantilever-type creep apparatus (from Ito and Akagi 2001), b multilever arm cantilever-type creep apparatus (from Okada 2006)

\subsection{Cantilever-Type Apparatus}

The cantilever-type apparatus has been used in creep tests since early times (Fig. 2). It is in practice the most suitable apparatus for creep tests because the load level can easily be kept constant with time. The greatest restrictions of this type of apparatus are the level of applicable load, which depends upon the length of the cantilever arm, and its oscillations during the application of the load. The cantilever-type apparatus utilizing a multi-arm lever overcomes the load limit restrictions (Okada 2005, 2006). The oscillation problem is also dealt with technically by the producers of such creep devices. If the load increase is done 
manually by placing dead-weights, as in some creep testing devices, utmost care must be taken during the loading procedure to prevent undesirable oscillations.

The load is applied onto samples by attaching deadweights to the lever, which may be done manually for lowstress creep tests or mechanically for high-stress creep tests. In triaxial experiments, special load cells are required and the confining pressure is generally provided through oil pressure. Utmost care must be taken in keeping the confining pressure constant in terms of a continuous power supply to the compressor of the confining pressure system.

Deformation and strain measurements can be taken in several ways. The simple approach is to utilize a couple of linear variable displacement transducers (LVDTs). When a triaxial creep experiment is carried out, the LVDTs may be fixed onto the sample and inserted into the triaxial chamber. In such a case, special precautions must be taken to ensure accurate measurement of displacements. Strain gages may be used. However, strain gages glued onto samples should be capable of measuring strain over a long period of time without any debonding. For lateral deformation or strain measurements, diametric or circumferential sensors can be used.

\subsection{Load/Displacement-Controlled Apparatus}

This type of apparatus is a servo-controlled testing machine that is capable of applying constant loads onto samples (Fig. 3). The most critical aspect of this experiment is to keep the axial stress acting on a sample constant, which requires continuous monitoring of the load and its automatic adjustment (i.e., Peng 1973). The load applied onto samples should be maintained to within $\pm 1 \%$ of the specified load. When triaxial creep tests are carried out, a special triaxial cell is used as in the previous case. Deformation or strain measurements are carried out in the same way as in the previous type of experiments. This type of experiment is generally used for creep tests under a high stress state.

There has been some concern with the use of this type of machine that vibrations associated with the constant high-speed operation of the closed loop, which ensures that the chosen parameter (in this case, stress) is kept constant, could affect the results through a fatigue effect. However, the authors are not aware of any evidence to this effect.
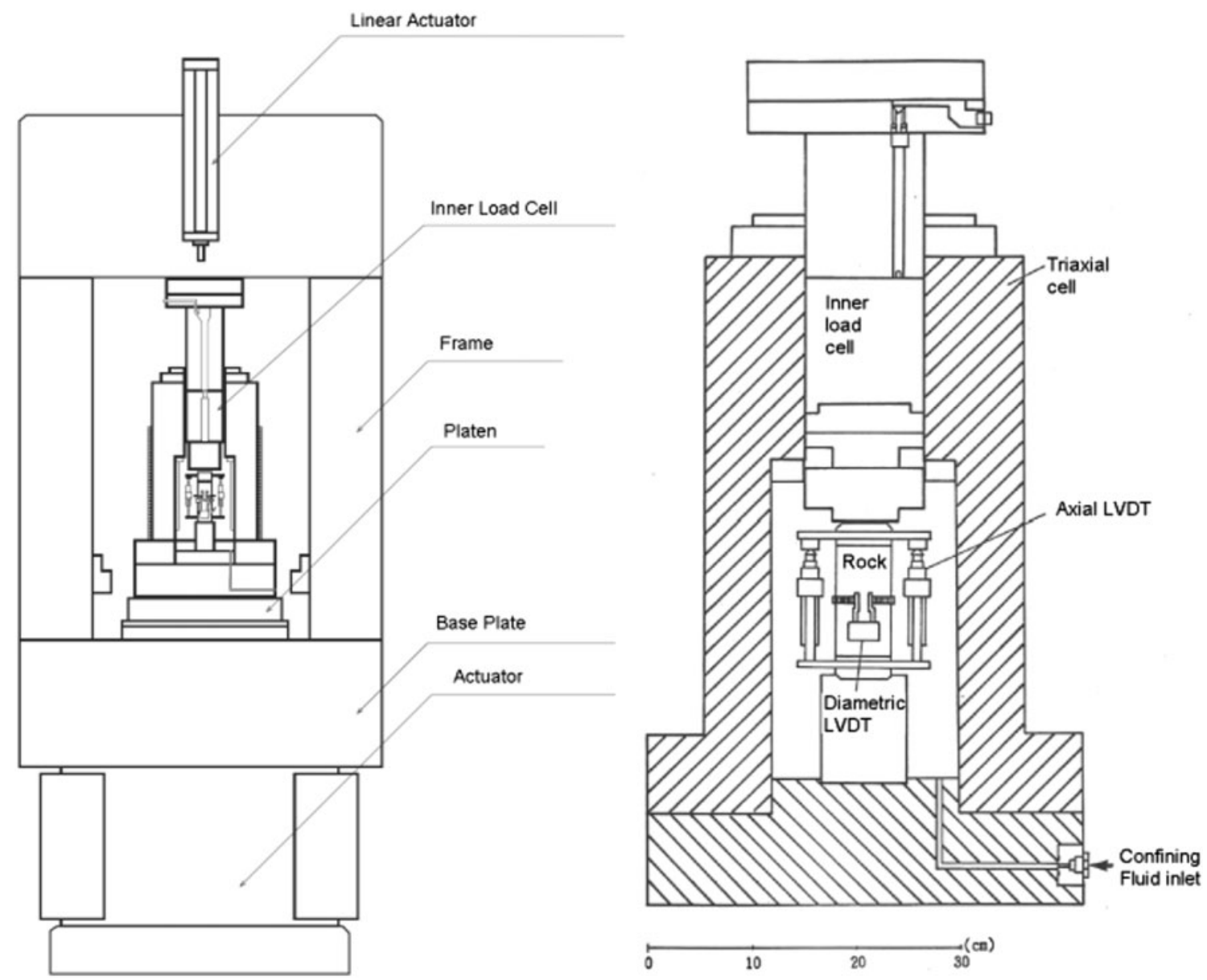

Fig. 3 Load/displacement-controlled apparatus (from Ishizuka et al. 1993) 
There are also true triaxial testing apparatuses to perform creep tests under true triaxial stress conditions (Serata et al. 1968; Adachi et al. 1969). The three principal stresses can be controlled independently in such triaxial testing apparatuses. Recent technological advances have made such tests easier to perform.

\section{Environmental Conditions}

The creep responses of some rocks, particularly evaporitic rocks, mudstone, and tuff, may be influenced by the humidity conditions. Furthermore, the creep responses of all rocks are influenced by temperature. As the results of creep experiments are generally influenced by environmental conditions, special considerations must be given to the environmental conditions. When necessary, creep experiments are carried out in climate-controlled rooms or in environmental chambers that are specially constructed around individual or multiple specimens. The environmental conditions are closely monitored and controlled within close tolerances.

\subsection{Temperature}

Creep tests in a room-temperature environment are carried out in climate-controlled rooms. However, when the creep behavior of rocks at different temperature levels is required, special heating units with thermal insulation are used. The temperature of a specimen measured at midheight under uniaxial condition and Brazilian tests or the inside temperature of the cell under triaxial stress condition should be maintained to within $\pm 1{ }^{\circ} \mathrm{C}$ of the required test temperature with a resolution of $\pm 0.1^{\circ} \mathrm{C}$.

\subsection{Humidity}

Some rocks, such as evaporitic rocks and clayey rocks, may be very sensitive to humidity conditions. According to the humidity requirement of creep tests, the humidity of climate-controlled rooms should be monitored and controlled within close tolerances of $\pm 5 \%$ (Wawersik 1983). If the humidity in the room cannot be controlled, the specimen should be sealed in a flexible membrane or coated with plastic or silicone rubber.

\subsection{Saturation}

The creep characteristics of many rocks are generally influenced by water saturation conditions. Special setups, shown in Fig. 4, may be used to achieve the appropriate saturation conditions. For performing creep experiments under different saturation conditions, the specimen should be sealed in a flexible membrane or coated with plastic or silicone rubber.

\section{Preparation and Size of Samples}

Specimen preparation for creep tests should follow the procedures of the ISRM suggested methods for the Brazilian, uniaxial compression, and triaxial compression tests (ISRM 2007). It is generally desirable to keep the size of samples as indicated in the suggested methods. However, the sample size may be smaller than the conventional sizes due to the loading limit of the device and the desired level of stress. In such circumstances, special care must be taken regarding the ratio of grain size to sample height, which should be less than 0.1 .
Fig. 4 Special setups for testing under dry and saturated conditions (from Ishizuka et al. 1993)

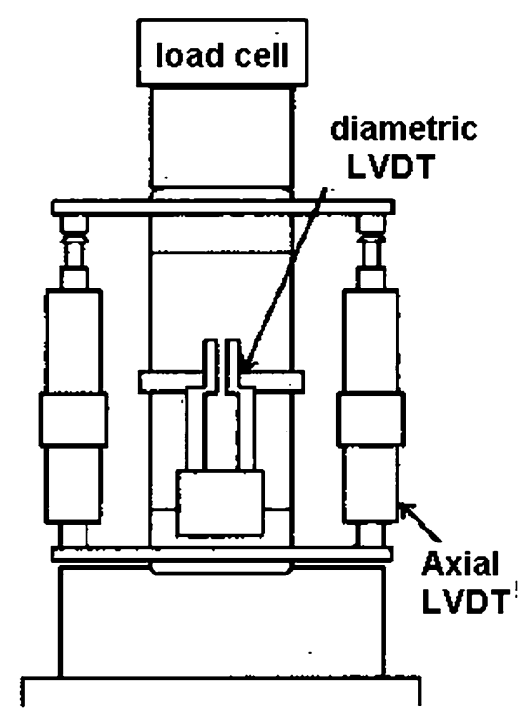

(a) Dry

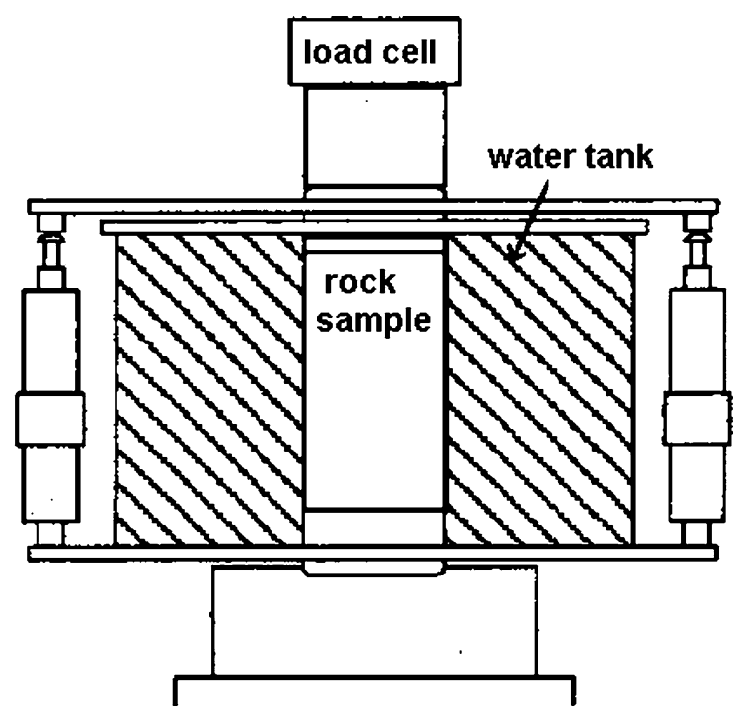

(b) Saturated 


\section{Testing Procedures}

\subsection{Uniaxial Compression Creep Tests}

The procedure described in the method suggested by the ISRM (2007) to test for uniaxial compressive strength should be followed unless the sample size differs from the conventional size. The displacement should be measured continuously or periodically (seconds, minutes, hours or days depending upon the stress level applied on samples) as suggested in the ISRM suggested methods. The load application rate may be higher than that used in the ISRM suggested methods when a cantilever-type apparatus is used. Once the load reaches the designated load level, it should be kept constant. If the experiments are to be carried out under saturated conditions, the sample should be put in a special water-filled cell as illustrated in Fig. 4b.

\subsection{Triaxial Compression Creep Tests}

The procedure described in the method suggested by the ISRM (2007) to determine triaxial compressive strength should be followed unless the sample size differs from the conventional size. Utmost care should be taken to monitor the axial load when the confining fluid is supplied into the triaxial cell. The displacement should be measured continuously or periodically as suggested in the ISRM suggested methods. The load application rate may be higher than that used in the ISRM suggested methods when a cantilever-type apparatus is used. Once the load reaches the designated load level, it should be kept constant. If the experiments are to be carried out under saturated conditions, the saturated sample should be sealed in a flexible membrane or coated with plastic or silicone rubber.

\subsection{Brazilian Creep Tests}

The loading jigs and procedure used in the method suggested by the ISRM (2007) for Brazilian tests should be followed unless the sample size differs from the conventional size. The displacement should be measured continuously or periodically as suggested in the ISRM suggested methods. The load application rate may be higher than that used in the ISRM suggested methods when a cantilevertype apparatus is used. Once the load reaches the designated load level, it should be kept constant. If the experiments are to be carried out under saturated conditions, the jigs and sample should be put in a special water-filled cell.

\subsection{Monitoring Irrecoverable Straining}

Determination of the elastoviscoplastic constitutive behavior of rocks requires that irrecoverable strains be monitored. The applied load (differential load in triaxial tests) should be reduced to a load level of $1 \%$ of the specified load, and the specimen should be reloaded at designated time intervals. The rate of loading during the reloading step should be the same as that used during the initial loading step.

\section{Calculations}

\subsection{Uniaxial and Triaxial Compression Creep Tests}

(a) Axial strain, $\varepsilon_{\mathrm{a}}$, and diametric strain, $\varepsilon_{\mathrm{d}}$, can be recorded directly from equipment indicating strain or can be calculated from deformation readings depending on the type of instrumentation used and illustrated in Figs. 3 and 4.

(b) Axial strain is calculated from the equation

$$
\varepsilon_{\mathrm{a}}=\frac{\Delta l}{l_{0}}
$$

where $l_{0}$ is the original measured axial length and $\Delta l$ is the change in measured axial length (defined to be positive for a decrease in length).

(c) (c) Diametric strain can be determined either by measuring the changes in the diameter of the specimen or by measuring the circumferential strain. In the case of measuring changes in diameter, the diametric strain is calculated from the equation

$$
\varepsilon_{\mathrm{d}}=\frac{\Delta d}{d_{0}},
$$

where $d_{0}$ is the original undeformed diameter of the specimen and $\Delta d$ is the change in diameter (defined to be negative for an increase in diameter). In the case of measuring the circumferential strain, $\varepsilon_{\mathrm{c}}$, the circumference is $C=\pi d$, thus the change in circumference is $\Delta C=\pi \Delta d$. Consequently, the circumferential strain, $\varepsilon_{\mathrm{c}}$, is related to the diametric strain, $\varepsilon_{\mathrm{d}}$, by

$$
\varepsilon_{\mathrm{c}}=\frac{\Delta C}{C}=\frac{\Delta d}{d_{0}},
$$

so that

$$
\varepsilon_{\mathrm{c}}=\varepsilon_{\mathrm{d}}
$$

where $C$ and $d_{0}$ are the original circumference and the diameter of the specimen, respectively.

(d) The compressive axial stress in the test specimen, $\sigma_{\mathrm{a}}$, is calculated by dividing the compressive load $P$ on the specimen by the initial cross-sectional area, $A_{0}$, i.e.,

$\sigma_{\mathrm{a}}=\frac{P}{A_{0}}$, 
where compressive stresses and strains are considered positive in this test procedure. For a given stress level, the volumetric strain, $\varepsilon_{\mathrm{v}}$, is calculated from the equation

$\varepsilon_{\mathrm{v}}=\varepsilon_{\mathrm{a}}+2 \varepsilon_{\mathrm{d}}$.

\subsection{Brazilian Creep Tests}

The tensile strength of the specimen should be calculated using the following formula:

$\sigma_{\mathrm{t}}=\frac{2}{\pi} \frac{P}{D t}$

where $P$ is the load at failure, $D$ is the diameter of the test specimen (mm), and $t$ is the thickness of the test specimen measured at its center $(\mathrm{mm})$. The nominal strain of the Brazilian tensile test sample can be given as (see Hondros 1959 and Jaeger and Cook 1979 for details)

$\varepsilon_{\mathrm{t}}=2\left[1-\frac{\pi}{4}(1-v)\right] \frac{\sigma_{\mathrm{t}}}{E}$ with $\varepsilon_{\mathrm{t}}=\frac{\delta}{D}$,

where $\delta, \varepsilon$ and $E$ are diametrical displacement in the loading direction, strain and elastic modulus, respectively.

If the Poisson's ratio of the rock is not known or not measured, one may choose a Poisson's ratio of 0.25 . Thus, the formula given above can be simplified to the following form (Aydan et al. 2011):

$\varepsilon_{\mathrm{t}}=0.82 \frac{\sigma_{\mathrm{t}}}{E}$.

\section{Reporting of Results}

The report should include the following:

(a) Lithologic description of the rock;

(b) Source of the sample, including geographic location, depth and orientation, dates of sampling and storage history, and environment;

(c) Orientation of the axis of loading with respect to specimen anisotropy, e.g., bedding planes, foliation, grain size, etc.;

(d) Number of specimens tested;

(e) Specimen diameter and height;

(f) Water content and degree of saturation at the time of test;

(g) Test duration and/or stress rate;

(h) Date of testing and type of testing machine;

(i) Mode of failure, e.g., location and orientation of failure surface;

(j) Any other observations or available physical data, such as specific gravity, porosity, and permeability, citing the method of determination of each;

(k) The applied stress level for each specimen in the sample expressed to three significant figures together
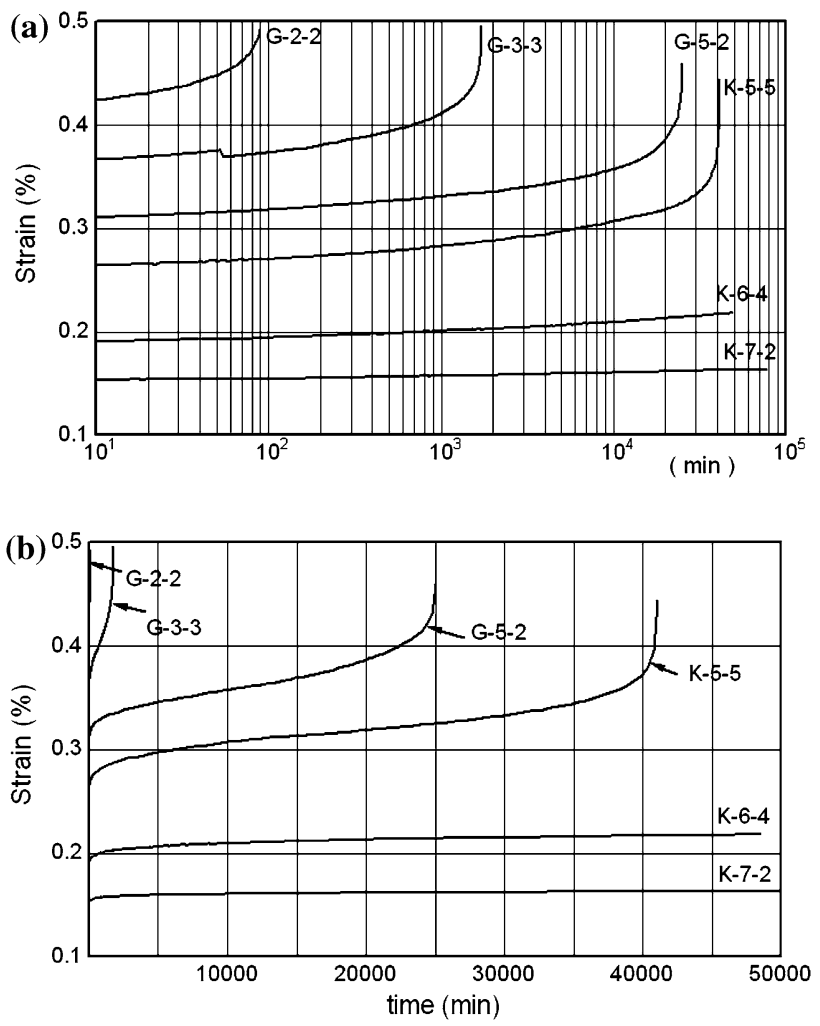

Fig. 5 Uniaxial compression creep response of Oya tuff (modified from Ito and Akagi 2001): a plot of experimental response on logarithmic scale, $\mathbf{b}$ plot of experimental results on linear scale

with the average result for the sample. Units of stress and strength must be given;

(1) If it is necessary in some instances to test specimens that do not comply with the above specifications, these facts should be noted in the test report;

(m) Results of creep experiments are generally presented in the space of time and strain for different combinations of experimental conditions (Fig. 5). Figure 6 shows the effect of saturation on the Brazilian and uniaxial compression creep responses of Cappadocian tuff samples from Zelve. Additional presentation may include failure time versus normalized applied stress by the short-term strength in both uniaxial and triaxial compression creep tests (Fig. 7). Figure 8 shows plots of responses during creep tests of Oya tuff and its failure time determined at different temperatures. Depending on the constitutive models chosen, the experimental results may be presented in different forms according to the user and his/her purpose. The "Appendix" included in the suggested methods provides some constitutive models for processing the results from creep experiments as advice to users. 


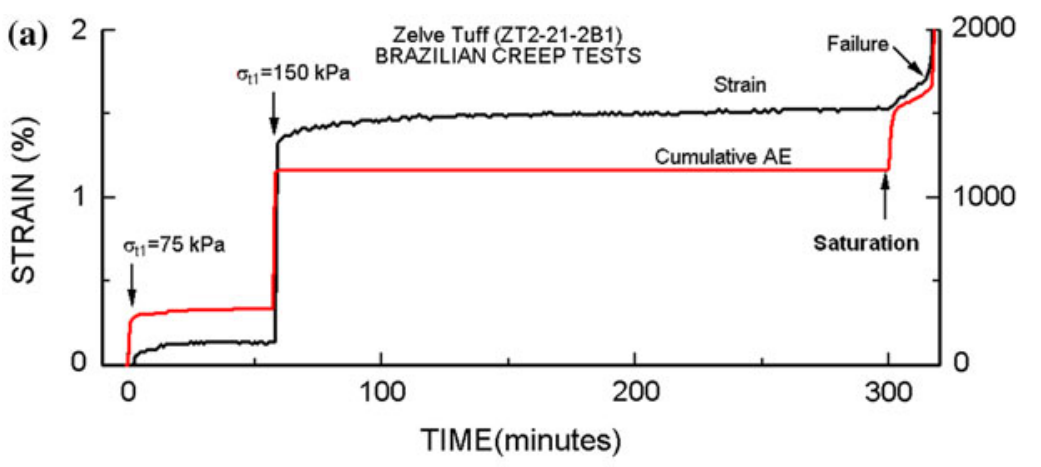

Fig. 6 Responses of initially dry and later saturated tuff samples from Zelve during Brazilian and uniaxial compression creep tests (arranged from Ito et al. 2008): a responses during Brazilian creep test of an initially dry and later saturated sample, b responses during a uniaxial compression creep test of an initially dry and later saturated sample

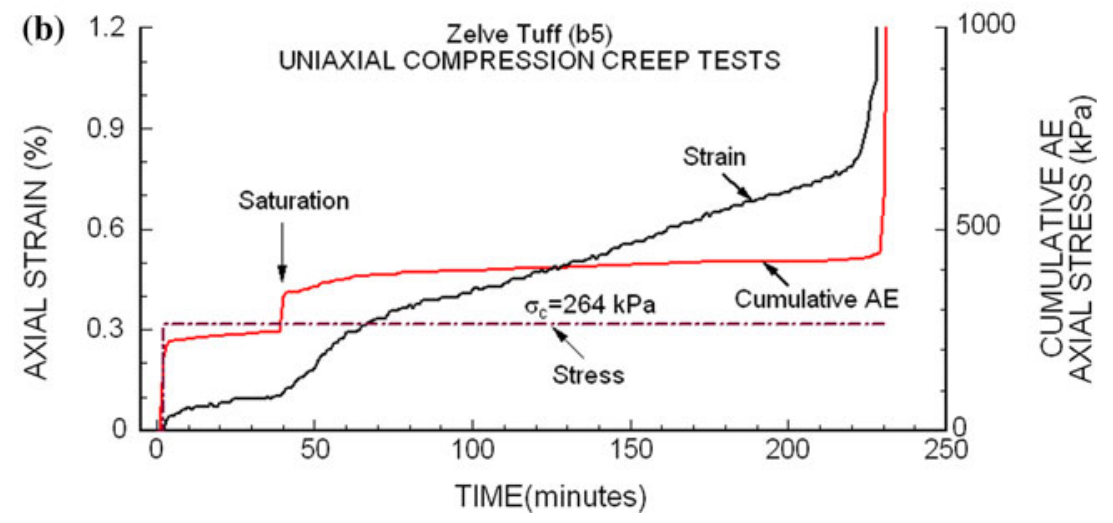

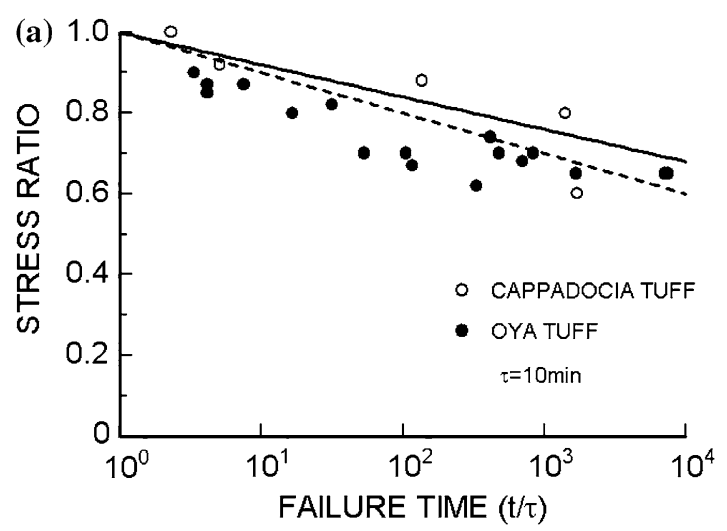

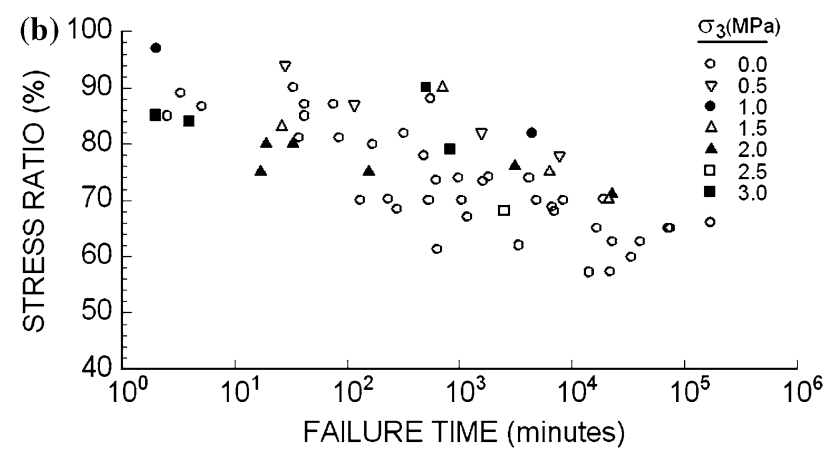

Fig. 7 a Creep failure time of Oya tuff and Cappadocia tuffs in uniaxial compression tests (from Ulusay et al. 1999). b Creep failure time of Oya tuff in triaxial compression tests (arranged from Ito et al. 1999; Shibata et al. 2007; Akai et al. 1979)
9 Notes and Recommendations

In this section some notes and recommendations are given. Some guidelines on how to utilize experimental results for modeling the time-dependent behavior of rocks are presented in the "Appendix."

\subsection{Power Backup}

As creep experiments may involve very long durations, utmost care must be taken to avoid power supply failures.

\subsection{Determination of Irrecoverable Strain}

Determination of parameters in relation to elastoviscoplastic constitutive laws may require irrecoverable strain and strain rates. In such cases, use of loading and unloading cycles will be necessary. Extra precautions must be taken to ensure that the load level is not less than $1 \%$ of the specified load level.

\subsection{Stability of Confining Fluid}

The confining pressure fluid should be stable at the temperature and pressure levels designated for the test. 

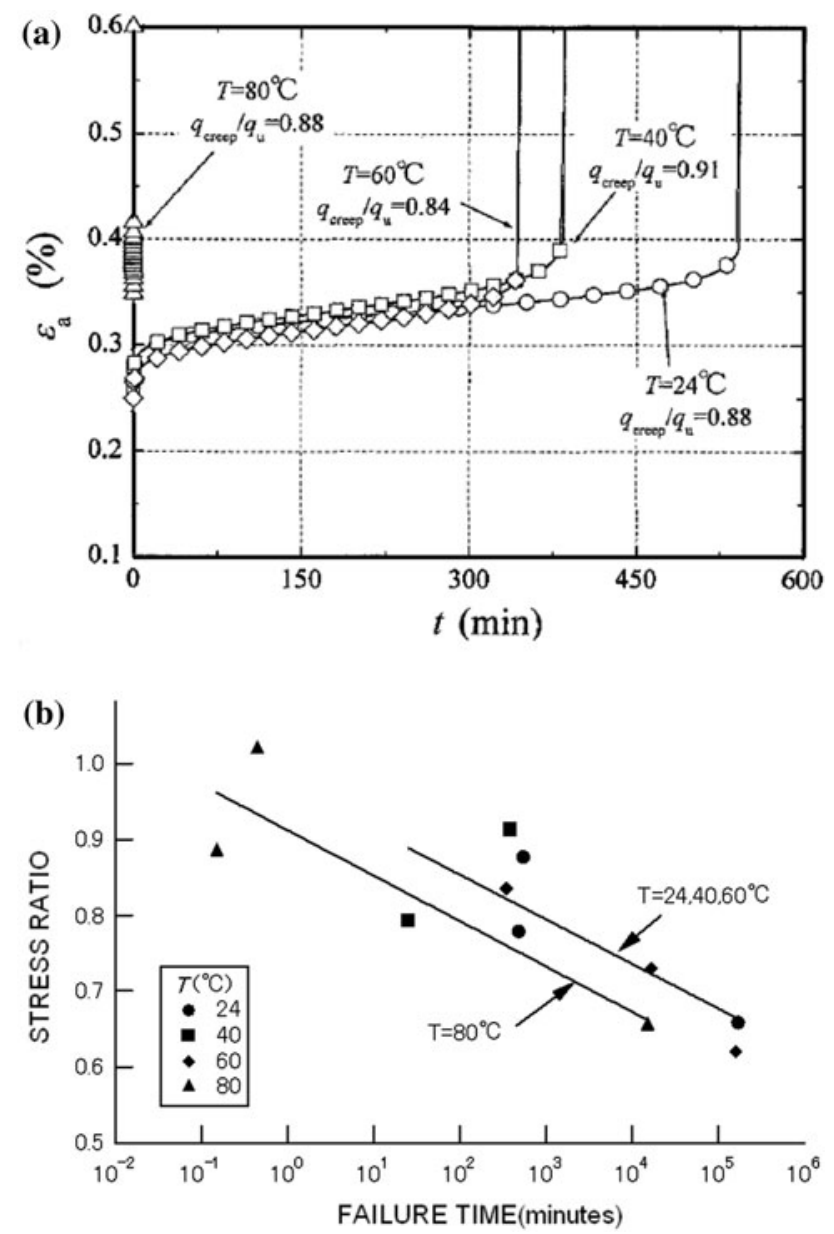

Fig. 8 a Creep response of Oya tuff. b Relationship between stress ratio and failure time at various temperatures (arranged from Shibata et al. 2007)

\subsection{Stability of Measuring Devices}

The measuring devices must remain stable at the temperature and pressure levels designated for the test.

\subsection{Safety of Test System}

Test systems under designated temperature and pressure levels must be compatible with the safety standards against system failure and fire. Furthermore, adequate protective shields should be used to protect people in the area from unexpected system failure.

Acknowledgments The members of this Working Group acknowledge the guidance and information given by Emeritus Prof. S. Sakurai, Japan and Emeritus Prof. J. A. Hudson (former presidents of the ISRM), Dr. N. Grossman (Portugal), Dr. W. R. Wawersik (USA), Dr. Eda Quadros (Brazil), Prof. P. Nawrocki (UAE), and Prof. R. Ulusay (Türkiye). Furthermore, Emeritus Professor John A. Hudson is thanked for his editorial assistance during the preparation of this document.

\section{Appendix}

Introduction

This "Appendix" is provided as supplementary material describing constitutive models available in the literature utilizing the experimental results of creep tests. As there have been numerous such models since the 1900s, it is impossible to cover all of them, and interested readers are recommended to consult textbooks, some of which are listed in the suggested methods reference list. Therefore, this "Appendix" has been prepared with the purpose of serving as a guideline to users utilizing the suggested methods. As defined in the "Introduction" of the suggested methods, a creep test is an experiment carried out under sustained loading condition, and the constitutive models are presented for such a condition.

It is claimed that creep behavior is not observed if the level of applied stress is less than a certain threshold value (Ladanyi 1993) in a practical sense (in terms of days).
Fig. 9 Illustration of threshold value and experimental results (arranged from Aydan et al. 1993, 1994)
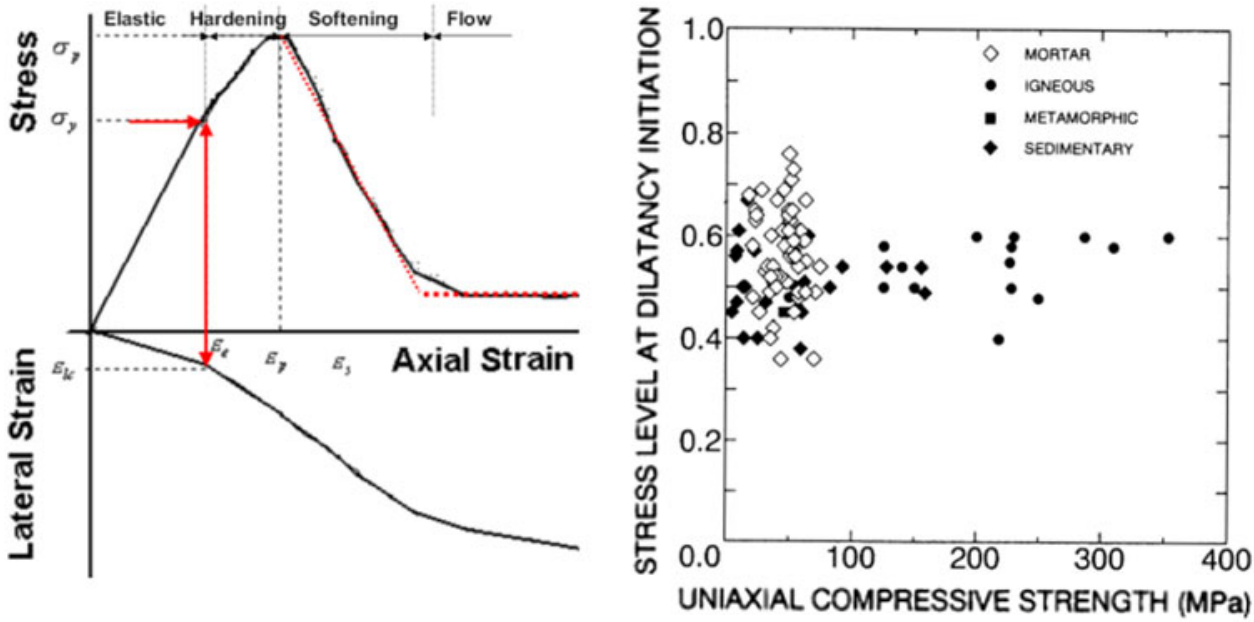


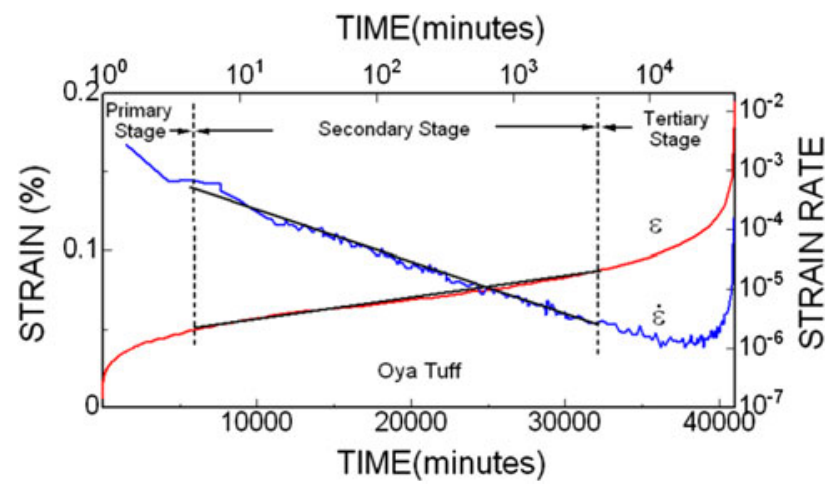

Fig. 10 Strain and strain rate response of a creep experiment on Oya tuff (Japan) shown in Fig. 5 in the main text

However, experiments carried out on igneous rock (granite, gabbro, etc.) beams by Ito (1991) for three decades show that a creep response definitely occurs even under very low stress levels. The threshold value suggested by Ladanyi (1993) may be associated with the initiation of dilatancy of volumetric strain as illustrated in Fig. 9. The initiation of dilatancy generally corresponds to $40-60 \%$ of the stress level, and fracture propagation tends to become unstable when the applied stress level exceeds $70-80 \%$ of the ultimate deviatoric strength for a given stress state (Aydan et al. 1994; Hallbauer et al. 1973). Therefore, the behavior below the threshold should generally correspond to viscoelastic behavior. The creep threshold according to Ladanyi (1974) should correspond to an elastoviscoplastic response, and it should not be possible to obtain viscoelastic properties directly from the measured responses.

As noted from Fig. 5 in the suggested methods, some responses terminate with failure while others become asymptotic to certain strain levels. The responses terminating in failure are generally divided into three stages as shown in Fig. 10 using one of the response curves shown in Fig. 5. These stages are defined as the primary, secondary, and tertiary creep stages. The secondary stage appears to be a linear response in time (but in fact, it is not a linear response). On the other hand, the tertiary stage is the stage in which the strain response increases exponentially, resulting in failure of the sample. Modeling of this stage in constitutive laws is an extremely difficult aspect as it also depends upon the boundary conditions.

The transitions from the primary to the secondary stage and from the secondary to the tertiary stage are generally determined from the deviation from a linearly decreasing or increasing strain rate plotted in logarithmic time space, as also shown in Fig. 10. Generally, it should, however, be noted that strain data must be smoothed before interpretation. Direct derivation of strain data containing actual responses as well as electronic noise may produce entirely different results. In this "Appendix," the constitutive laws are divided into two categories, namely unidirectional and

Table 1 Intuitive unidimensional creep models (except for Aydan et al. 2003 the references to the citations in this table can be found in Farmer 1983)

\begin{tabular}{|c|c|c|}
\hline Proposed by & Formula & Comments \\
\hline Andrade $(1910,1914)$ & $\varepsilon_{c}=B t^{1 / \beta}$ & $\begin{array}{l}\text { Applicable } \quad \text { to } \quad \text { primary } \\
\text { stage; } \beta=3 ;\end{array}$ \\
\hline Lomnitz $(1956,1957)$ & $\varepsilon_{c}=A \ln (1+\alpha t)$ & Applicable to primary stage \\
\hline Modified Lomnitz law & $\varepsilon_{c}=A+B \log (t)+C t$ & Primary and secondary stages \\
\hline Norton's law & $\begin{array}{l}\varepsilon_{c}=A \sigma_{a}^{n} t \text { or } \\
\varepsilon_{c}=A \sigma_{a}^{n}\end{array}$ & $\begin{array}{l}\text { Applicable to secondary stage } \\
\text { and } n=4-5\end{array}$ \\
\hline Modified Norton's law & $\begin{aligned} \varepsilon_{c} & =B\left\langle\frac{\sigma_{a}}{\sigma_{c t}}-1\right\rangle^{n} t \text { or } \\
\varepsilon_{c} & =B\left\langle\frac{\sigma_{a}}{\sigma_{c t}}-1\right\rangle^{n}\end{aligned}$ & $\begin{array}{l}\text { Applicable to secondary stage } \\
\text { and } \sigma_{c t} \text { is the stress threshold } \\
\text { to induce steady state creep } \\
\text { response. }\end{array}$ \\
\hline $\begin{array}{l}\text { Griggs and Coles } \\
(1958)\end{array}$ & $\varepsilon_{c}=A+B t^{2}$ & Applicable to tertiary stage \\
\hline Aydan et al. (2003) & $\varepsilon_{c}=A\left(1-e^{-t / \tau_{1}}\right)+B\left(e^{t / \tau_{2}}-1\right)$ & $\begin{array}{l}\text { Applicable to all stages creep } \\
\text { leading to failure }\end{array}$ \\
\hline
\end{tabular}

$A, B, C, \alpha, \tau_{1}, \tau_{2}$, and $n$ are constants to be determined from experimental results. $\sigma_{\mathrm{a}}, \varepsilon_{\mathrm{c}}, \dot{\varepsilon}_{\mathrm{c}}$, and $t$ are the applied stress, creep strain, strain rate, and time, respectively, hereafter 
Table 2 Rheological models for unidimensional constitutive modeling

\begin{tabular}{|l|l|c|}
\hline \multicolumn{1}{|c|}{ Model } & \multicolumn{1}{|c|}{ Formula } & \\
\hline Hooke & $\sigma_{a}=E \varepsilon$ & $\sigma_{a}=\eta \dot{\varepsilon}$ \\
\hline Newton & $\varepsilon=\frac{\sigma_{a}}{E}\left(1-e^{-t / t_{r}}\right) ; t_{r}=\frac{\eta}{E}$ & \\
\hline Voigt-Kelvin & $\varepsilon=\frac{\sigma_{a}}{E}+\frac{\sigma_{a}}{\eta} t$ & \\
\hline $\begin{array}{l}\text { Generalized } \\
\text { Voigt-Kelvin }\end{array}$ & $\varepsilon=\frac{\sigma_{a}}{E_{h}}+\frac{\sigma_{a}}{E_{k}}\left(1-e^{-t / t_{r}}\right) ; t_{r}=\frac{\eta}{E_{k}}$ \\
\hline $\begin{array}{l}\text { Hill-Maxwell } \\
\text { model }\end{array}$ & $\varepsilon=\frac{\sigma_{a}}{E_{h}}\left[1-\frac{E_{m}}{E_{h}+E_{m}} e^{-t / t_{r}}\right.$ \\
\hline $\begin{array}{l}\text { Burgers } \\
E_{m}\end{array}$ & $t_{k}=\frac{\eta_{k}}{E_{k}}$ \\
\hline$E_{k}$
\end{tabular}

$E$ and $\eta$ are elastic and viscosity moduli, respectively. Suffixes "h," "k," and "m" indicate moduli of Hooke, Kelvin, and Maxwell units. $\varepsilon$ is total strain

multidimensional constitutive laws. These constitutive laws and available yield functions are briefly outlined and discussed together with some examples of applications.

\section{Unidimensional Constitutive Models}

Constitutive models are essentially based on responses obtained from experiments and fundamentally are fitting procedures of some functions to experimental results. Therefore, they cannot be purely derived from a certain theory. Nevertheless, they must satisfy certain rules established in constitutive modeling of material science. Unidimensional constitutive models can also be broadly divided into two categories: intuitive models and rheological models. Table 1 summarizes some of the wellknown intuitive models, while Table 2 summarizes linear rheological models (Mirza 1978; Doktan 1983; Farmer 1983). Figure 11 compares experimental responses with those from intuitive and rheological models. As can be noted from this figure, each model has its own merits and demerits, and the user should decide which one to adopt for his/her purpose.

When the behavior of rock includes irrecoverable (permanent) strain, nonlinear rheological models have also been developed, and some of them are listed in Table 3 and their responses compared in Fig. 12. Expressions for elastoviscoplastic models can be developed in a similar manner. However, they tend to be rather complicated. Also, it should be noted that such models require the determination of the irrecoverable response from experiments, which definitely requires the implementation of loading and unloading procedures. 

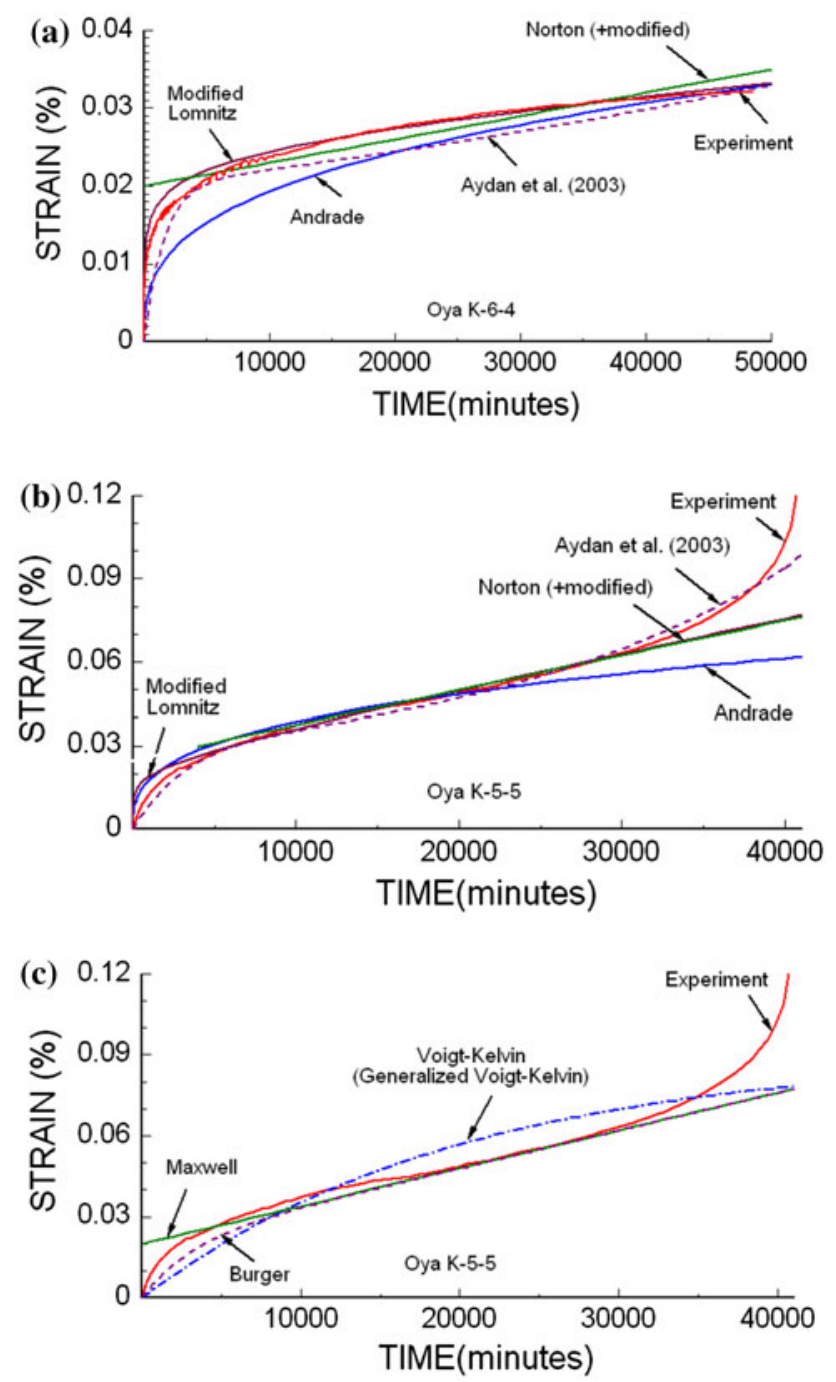

Fig. 11 Comparison of intuitive and rheological models with experimental responses: a asymptotic response (intuitive models), b response terminating with failure (intuitive models), and c response terminating with failure (rheological models)

\section{Multidimensional Constitutive Models}

Some of the linear models are listed in Table 4. In particular, the rheological models presented in the previous section can be extended to the multidimensional situation. However, the algebra involved in developing the relations between total stress and total strain may become quite cumbersome. For an isotropic homogeneous rock material, if the coefficients to determine the lateral components for a given direction are time independent, it may be possible to develop constitutive relations between the total stress and total strain in analogy to those presented in the previous sections. However, the general situation would require some numerical integration and complex algebra.
Nonlinear behavior involving irrecoverable (permanent) responses is more difficult to model by constitutive models. Particularly, it is cumbersome to determine the parameters of constitutive models from experimental data. Therefore, it is quite common to introduce the effective stress $\left(\sigma_{\mathrm{e}}\right)$ and effective strain $\left(\varepsilon_{\mathrm{e}}\right)$ concepts (these are different concepts from that used for the effect of pore water pressure on the stress tensor) if the irrecoverable part of the strain tensor is independent of the volumetric component. They are defined as follows:

$\sigma_{\mathrm{e}}=\sqrt{\frac{3}{2} \mathbf{s} \cdot \mathbf{s}}$ and $\quad \varepsilon_{\mathrm{e}}=\sqrt{\mathbf{e}_{\mathrm{p}} \cdot \mathbf{e}_{\mathrm{p}}}$

where $\mathbf{s}$ and $\mathbf{e}$ are the deviatoric stress and deviatoric strain tensors, respectively, as given below

$\mathbf{s}=\boldsymbol{\sigma}-\frac{\operatorname{tr}(\boldsymbol{\sigma})}{3} \mathbf{I} \quad$ and $\quad \mathbf{e}_{\mathrm{p}}=\boldsymbol{\varepsilon}_{\mathrm{p}}-\frac{\operatorname{tr}\left(\boldsymbol{\varepsilon}_{\mathrm{p}}\right)}{3} \mathbf{I}$ with $\operatorname{tr}\left(\boldsymbol{\varepsilon}_{\mathrm{p}}\right)=0$.

It is interesting to note that the effective stress and strain correspond to those in a uniaxial state, i.e.,

$\sigma_{\mathrm{e}}=\sigma_{1} \quad$ and $\quad \varepsilon_{\mathrm{e}}=\varepsilon_{1}$.

This leads to the very convenient conclusion that the nonlinear response can be evaluated under a uniaxial state and easily extended to the multidimensional state without any triaxial testing. However, it should be noted that this is only valid when the volumetric components are negligible in the overall mechanical behavior.

Some of the nonlinear models are listed in Table 5. The viscoelastoplastic model by Aydan and Nawrocki (1998) is illustrated in Fig. 13 for a one-dimensional situation.

\section{Yield Functions}

There is no yield (failure) criterion directly incorporating the effect of creep experiments (Aydan and Nawrocki 1998; Aydan et al. 2012), although the basic concept has been presented previously (Ladanyi 1974) for the timedependent response of tunnels. Based on the yielding concept shown in Fig. 9, some of the yield criteria are listed in Table 6. The general form of the plastic potential functions is also assumed to be similar to yield criteria. If a plastic potential function is assumed to be the same as a yield criterion, it corresponds to the associated flow rule.

Aydan and Nawrocki (1998) discussed how to incorporate the results of creep experiments into yield functions on the basis of the results of rare triaxial creep experiments. On the basis of the experimental results on various rocks by several researchers (Ishizuka et al. 1993; Kawakita et al. 1981; Masuda et al. 1987; Aydan et al. 1995), Aydan and 
Table 3 Rheological unidimensional nonlinear creep models

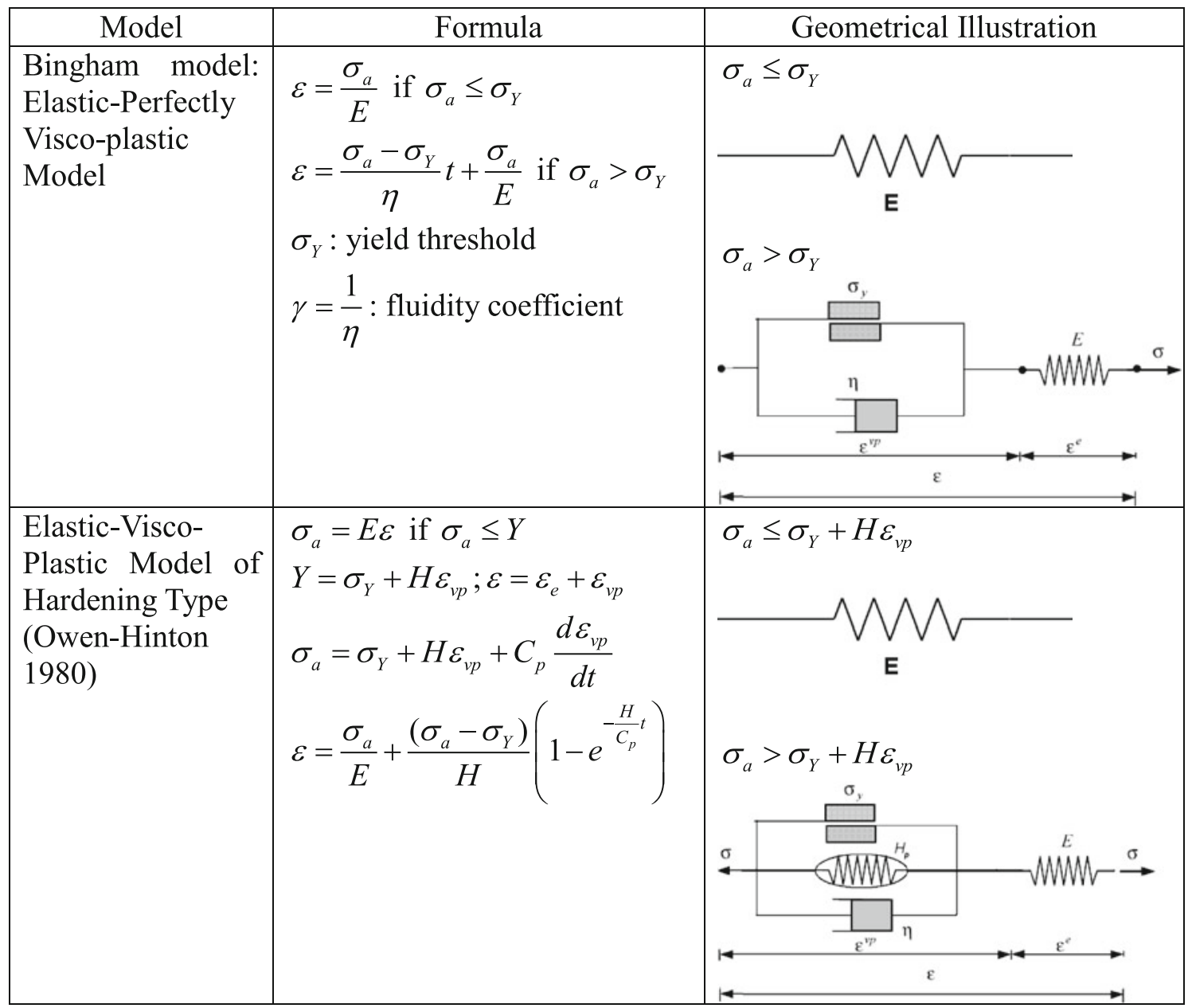

$\varepsilon_{\mathrm{e}}$ and $\varepsilon_{\mathrm{vp}}$ are elastic and viscoplastic components of strain. $H$ and $C_{\mathrm{p}}$ are plastic hardening modulus and viscoplastic modulus, respectively

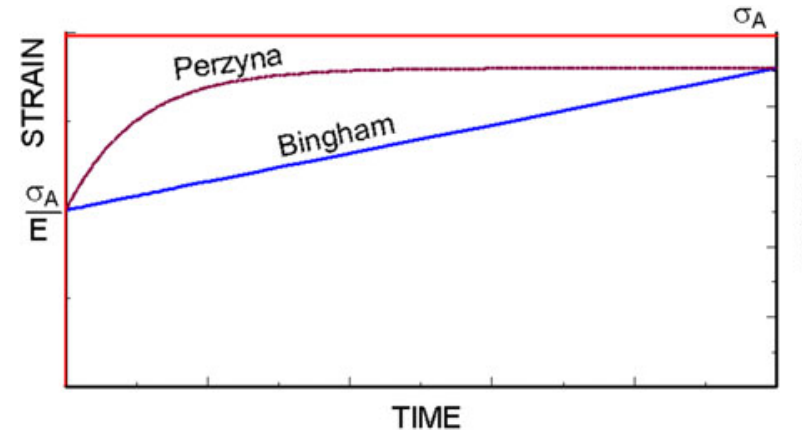

Fig. 12 Comparison of Bingham- and Perzyna-type viscoplastic responses
Nawrocki (1998) concluded that the time dependency of the friction angle is quite negligible and the time dependency of the cohesive component of the yield criterion should be sufficient for incorporation of the results of creep experiments. Creep experiments would generally yield a decrease of the deviatoric strength in time in view of the experimental results shown in Fig. 6 of the suggested methods, which would correspond to shrinkage of the yield surface in time as shown in Fig. 14.

Based on the concept given above, the time-dependent uniaxial compressive strength $\left[\sigma_{\mathrm{c}}(t)\right]$ of Oya tuff (Japan) and Cappadocia tuff (Turkey) shown in Fig. 6 in the 
Table 4 Linear models

\begin{tabular}{|l|l|l|}
\hline \multicolumn{1}{|c|}{ Model } & \multicolumn{1}{|c|}{ Formula } & \multicolumn{1}{c|}{ Comments } \\
\hline Newton type & $\begin{array}{l}\sigma_{i j}=C_{i j k l} \dot{\varepsilon}_{k l} \text { or } \\
\sigma_{i j}=2 \mu^{*} \dot{\varepsilon}_{i j}+\lambda * \delta_{i j} \dot{\varepsilon}_{k k}\end{array}$ & $\begin{array}{l}C_{i j k l} \text { : viscosity tensor } \\
\lambda * \text { and } \mu * \text { are viscous } \\
\text { Lame coefficients }\end{array}$ \\
\hline $\begin{array}{l}\text { Voigt-Kelvin } \\
\text { type }\end{array}$ & $\sigma_{i j}=D_{i j k l} \varepsilon_{k l}+C_{i j k l} \dot{\varepsilon}_{k l}$ or & $\begin{array}{l}D_{i j k l}: \text { elasticity tensor } \\
\lambda \text { and } \mu \text { are elastic Lame } \\
\text { coefficient }\end{array}$ \\
\hline Maxwell type & $\sigma_{i j}=2 \mu \varepsilon_{i j}+\lambda \delta_{i j} \varepsilon_{k k}+2 \mu^{*} \dot{\varepsilon}_{i j}+\lambda * \delta_{i j} \dot{\varepsilon}_{k k}$ & $\begin{array}{l}E_{i j k l} \text { and } F_{i j k l} \text { are } \\
\text { elasticity and viscosity } \\
\text { compliance tensors }\end{array}$ \\
\hline
\end{tabular}

$\sigma_{i j}, \varepsilon_{k l}$, and $\dot{\varepsilon}_{k l}$ are stress, strain, and strain rate tensors, respectively

Table 5 Nonlinear models

\begin{tabular}{|c|c|c|c|}
\hline Model & & Formula & Comment \\
\hline \multirow[t]{2}{*}{$\begin{array}{l}\text { Elastic- } \\
\text { visco- } \\
\text { plastic }\end{array}$} & $\begin{array}{l}\text { Power } \\
\text { Law }\end{array}$ & $\frac{d \boldsymbol{\varepsilon}_{v p}}{d t}=\left(\frac{\sigma_{e q}}{\sigma_{o}}\right)^{n} \frac{\partial \sigma_{e q}}{\partial \boldsymbol{\sigma}}$ with $\mathbf{e}_{v p}=\boldsymbol{\varepsilon}_{v p}$ & \\
\hline & $\begin{array}{l}\text { Perzyna } \\
\text { model }\end{array}$ & $\begin{array}{l}\frac{d \boldsymbol{\varepsilon}_{v p}}{d t}=\lambda \mathbf{s} \text { and } \lambda \text { is determined from } \\
\text { experimental response using the } \\
\text { following relation } \\
\lambda=\frac{\dot{\varepsilon}_{c}}{\sigma} \\
\text { Flow rule } d \dot{\boldsymbol{\varepsilon}}^{p}=\dot{\lambda} \frac{\partial G}{\partial \boldsymbol{\sigma}}\end{array}$ & $\begin{array}{l}\lambda \text { is interpreted called } \\
\text { as fluidity coefficient. } \\
\text { Flow rule implies that } \\
\text { any plastic straining is } \\
\text { time-dependent }\end{array}$ \\
\hline \multirow{2}{*}{$\begin{array}{l}\text { Elasto- } \\
\text { visco- } \\
\text { plastic }\end{array}$} & \multirow{2}{*}{$\begin{array}{l}\text { Aydan } \\
\text { Nawrocki } \\
\text { model }\end{array}$} & $\begin{aligned} d \boldsymbol{\sigma} & =\mathbf{D}^{r p} d \boldsymbol{\varepsilon}+\mathbf{C}^{r p} d \dot{\boldsymbol{\varepsilon}} \\
\mathbf{D}^{r p} & =\mathbf{D}^{r}-\frac{\mathbf{D}^{r} \frac{\partial G}{\partial \boldsymbol{\sigma}} \otimes \frac{\partial F}{\partial \boldsymbol{\sigma}} \mathbf{D}^{r}}{}\end{aligned}$ & \multirow{2}{*}{$\begin{array}{l}\text { Flow rule implies that } \\
\text { the plastic potential } \\
\text { function expands or } \\
\text { shrinks in time } \\
\text { domain and strain } \\
\text { increments consists of } \\
\text { time-dependent and } \\
\text { time independent } \\
\text { parts }\end{array}$} \\
\hline & & $\begin{array}{l}\mathbf{D}^{r p}=\mathbf{D}^{r}-\frac{\partial \boldsymbol{\sigma}}{h_{r p}+\frac{\partial F}{\partial \boldsymbol{\sigma}} \cdot\left(\mathbf{D}^{r} \frac{\partial G}{\partial \boldsymbol{\sigma}}\right)+\frac{\partial F}{\partial \boldsymbol{\sigma}} \cdot\left(\mathbf{C}^{r} \frac{\partial \dot{G}}{\partial \boldsymbol{\sigma}}\right)} \\
\mathbf{C}^{r p}=\mathbf{C}^{r}-\frac{\mathbf{C}^{r} \frac{\partial \dot{G}}{\partial \boldsymbol{\sigma}} \otimes \frac{\partial F}{\partial \boldsymbol{\sigma}} \mathbf{C}^{r}}{h_{r p}+\frac{\partial F}{\partial \boldsymbol{\sigma}} \cdot\left(\mathbf{D}^{r} \frac{\partial G}{\partial \boldsymbol{\sigma}}\right)+\frac{\partial F}{\partial \boldsymbol{\sigma}} \cdot\left(\mathbf{C}^{r} \frac{\partial \dot{G}}{\partial \boldsymbol{\sigma}}\right)} \\
\text { Flow rule } d \dot{\boldsymbol{\varepsilon}}^{p}=\lambda \frac{\partial \dot{G}}{\partial \boldsymbol{\sigma}}\end{array}$ & \\
\hline
\end{tabular}

$F$ and $G$ are yield and plastic potential functions, respectively. Indices " $r$ " and " $p$ " stand for adjectives "recoverable" and "permanent" respectively 
Fig. 13 Illustration of viscoelastoplastic model by Aydan and Nawrocki (1998) for a one-dimensional situation
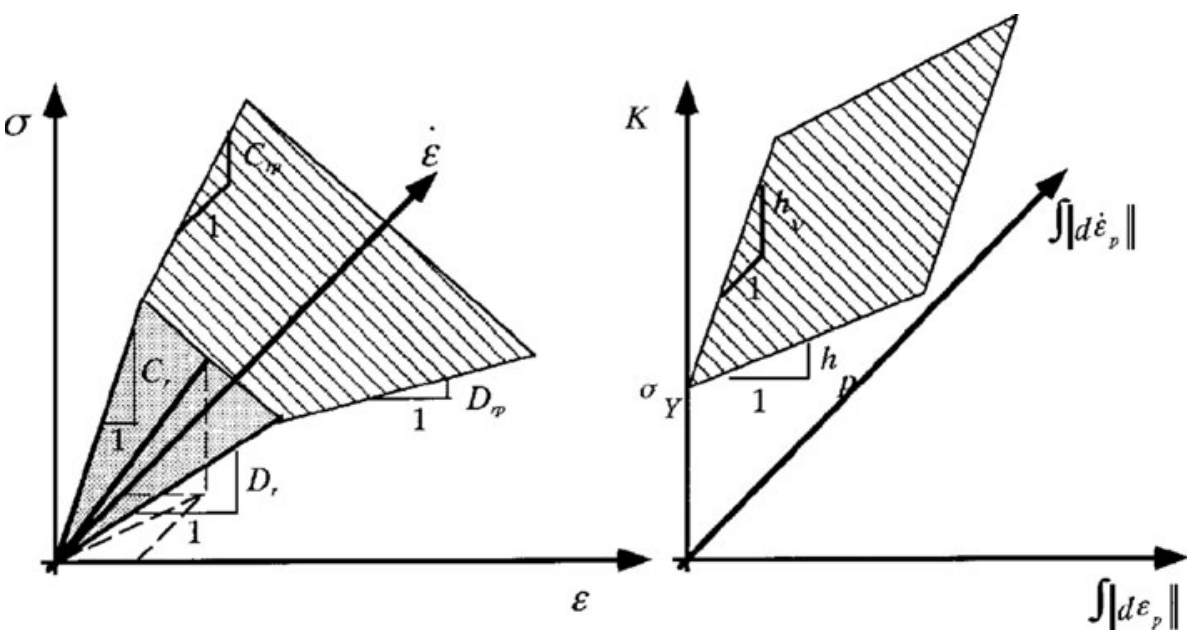

Table 6 Yield criteria (see Aydan et al. 2012 for details)

\begin{tabular}{|c|c|c|}
\hline Model & Formula & Comments \\
\hline Mohr-Coulomb & $\begin{array}{l}\tau=c+\sigma_{n} \tan \phi \text { or } \sigma_{1}=\sigma_{c}+q \sigma_{3} \\
\sigma_{c}=\frac{2 c \cos \phi}{1-\sin \phi} ; \sigma_{t}=\frac{2 c \cos \phi}{1+\sin \phi} ; q=\frac{1+\sin \phi}{1-\sin \phi}\end{array}$ & $\begin{array}{l}c: \text { cohesion } \\
\phi: \text { friction angle } \\
\sigma_{t}: \text { tensile strength } \\
\sigma_{c}: \text { uniaxial } \\
\text { compressive strength }\end{array}$ \\
\hline $\begin{array}{l}\text { Drucker-Prager } \\
\text { (Drucker and } \\
\text { Prager 1952) }\end{array}$ & $\begin{array}{l}\alpha I_{1}+\sqrt{J_{2}}=k \\
I_{1}=\sigma_{1}+\sigma_{2}+\sigma_{3} \\
J_{2}=\frac{1}{6}\left(\left(\sigma_{1}-\sigma_{2}\right)^{2}+\left(\sigma_{2}-\sigma_{3}\right)^{2}+\left(\sigma_{3}-\sigma_{1}\right)^{2}\right.\end{array}$ & $\begin{array}{l}\alpha=\frac{2 \sin \phi}{\sqrt{3}(3 \pm \sin \phi)} \\
k=\frac{6 c \cos \phi}{\sqrt{3}(3 \pm \sin \phi)} \\
-: \text { outer apexes } \\
+: \text { inner apexes }\end{array}$ \\
\hline $\begin{array}{l}\text { Hoek-Brown } \\
(1980)\end{array}$ & $\sigma_{1}=\sigma_{3}+\sqrt{m \sigma_{c} \sigma_{3}+\sigma_{c}^{2}}$ & $m=\frac{\sigma_{c}^{2}-\sigma_{t}^{2}}{\sigma_{c} \sigma_{t}}$ \\
\hline Aydan (1995) & $\sigma_{1}=\sigma_{3}+\left[S_{\infty}-\left(S_{\infty}-\sigma_{c}\right) e^{-b_{1} \sigma_{3}}\right] e^{-b_{2} T}$ & $\begin{array}{l}\sigma_{\infty}: \text { the ultimate } \\
\text { deviatoric strength } \\
T: \text { temperature } \\
b_{1}, b_{2}: \text { constants. }\end{array}$ \\
\hline
\end{tabular}

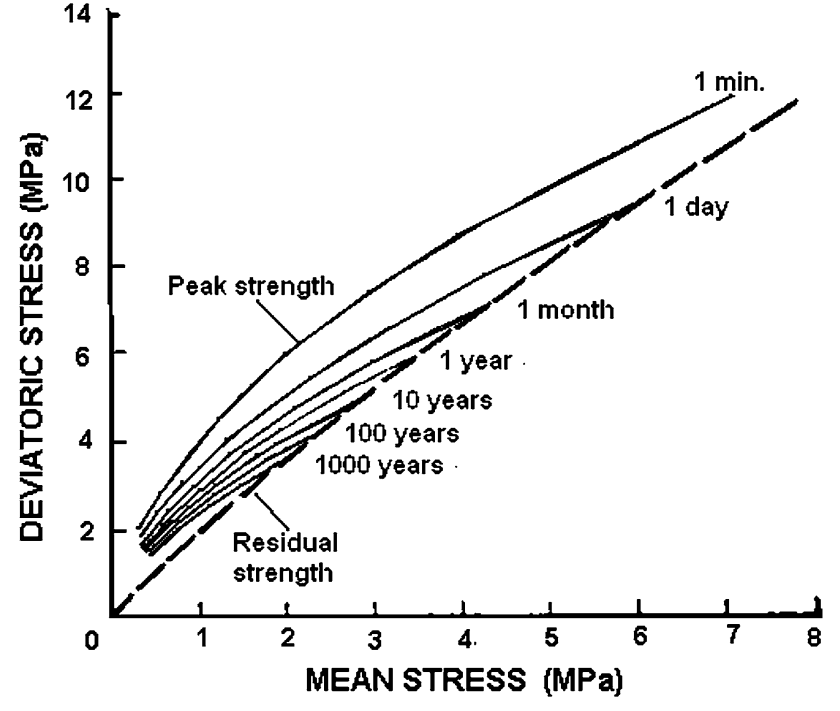

suggested methods can be represented in terms of their uniaxial compressive strength $\left(\sigma_{\mathrm{cs}}\right)$ and the duration $(\tau)$ of a short-term experiment by the following function (Aydan and Nawrocki 1998; Aydan and Ulusay 2013):

$\frac{\sigma_{\mathrm{c}}(t)}{\sigma_{\mathrm{cs}}}=1.0-b \ln \left(\frac{t}{\tau}\right)$.

The value of $b$ in Eq. 12 for Oya tuff and Cappadocia tuffs is 0.08 and 0.05 , respectively. However, functions different from that given by Eq. 12 can be used provided that they fit the experimental results (Aydan et al. 2011).

Fig. 14 Illustration of the failure criterion for fully saturated Oya tuff at various times estimated by Adachi and Takase (1981) 


\section{References}

Adachi T, Takase A (1981) Prediction of long term strength of soft rocks. In: Proceedings of international symposium on weak rock, pp 99-104

Adachi T, Sarata S, Sakurai S (1969) Determination of underground stress field based on inelastic properties of rocks. In: Proceedings of 11th symposium on rock mechanics, University of California, Berkeley, pp 293-328

Akagi T (1976) An analytical research on the visco-elastic behaviour of civil engineering structures. Doctorate thesis, Nagoya University (in Japanese)

Akagi T, Ichikawa Y, Kuroda T, Kawamoto T (1984) A non-linear rheological analysis of deeply located tunnels. Int J Num Anal Meth Geomech 8:107-120

Akai K, Adachi T, Nishi K (1979) Time dependent characteristics and constitutive equations of soft sedimentary rocks (porous tuff). Proc JSCE 282-2:75-87 (in Japanese)

Aydan Ö (1995) The stress state of the earth and the earth's crust due to the gravitational pull. The 35 th US rock mechanics symposium, Lake Tahoe, pp 237-243

Aydan Ö, Nawrocki P (1998) Rate-dependent deformability and strength characteristics of rocks. In: International symposium on the geotechnics of hard soils-soft rocks, Napoli, vol 1, pp 403-411

Aydan Ö, Ulusay R (2013) Studies on Derinkuyu antique underground city and its implications in geo-engineering. Rock Mech Rock Eng. doi:10.1007/s00603-012-0301-7

Aydan Ö, Akagi T, Kawamoto T (1993) Squeezing potential of rocks around tunnels; theory and prediction. Rock Mech Rock Eng 26(2):137-163

Aydan Ö, Seiki T, Jeong GC, Tokashiki N (1994) Mechanical behaviour of rocks, discontinuities and rock masses. In: Proceedings of international symposium pre-failure deformation characteristics of geomaterials, Sapporo, vol 2, pp 1161-1168

Aydan Ö, Akagi T, Ito T, Ito J, Sato J (1995) Prediction of deformation behaviour of a tunnel in squeezing rock with timedependent characteristics. In: Proceedings of numerical models in geomechanics NUMOG V, pp 463-469

Aydan Ö, Tokashiki N, Ito T, Akagi T, Ulusay R, Bilgin HA (2003) An experimental study on the electrical potential of nonpiezoelectric geomaterials during fracturing and sliding. In: 9th ISRM congress, South Africa, pp 73-78

Aydan Ö, Rassouli F, Ito T (2011) Multi-parameter responses of Oya tuff during experiments on its time-dependent characteristics. In: Proceedings of the 45th US rock mechanics/geomechanics symposium, San Francisco, ARMA, pp 11-294

Aydan Ö, Tokashiki N, Geniş M (2012) Some considerations on yield (failure) criteria in rock mechanics ARMA 12-640. In: Proceedings of 46th US rock mechanics/geomechanics symposium, Chicago, $10 \mathrm{p}$ (on CD)

Berest P, Blum P, Charpentier J, Gharbi H, Vales F (2005) Very slow creep tests on rock samples. Int J Rock Mech Min Sci 42:569-576

Bieniawski ZT (1970) Time-dependent behaviour of fractured rock. Rock Mech 2:123-137

Boukharov GN, Chandi MW, Boukharov NG (1995) The three processes of brittle crystalline rock creep. Int J Rock Mech Min Sci Geomech Abstr 32 (4):325-335

Chan KS (1997) A damage mechanics treatment of creep failure in rock salt. Int J Damage Mech 6:122-152

Cristescu ND, Hunsche U (1998) Time effects in rock mechanics. Wiley, New York

Doktan M (1983) The longterm stability of room and pillar workings in a gypsum mine, Ph.D. thesis, University of Newcastle Upon Tyne
Drucker DC, Prager W (1952) Soil mechanics and plastic analysis for limit design. Q Appl Math 10(2):157-165

Fabre G, Pellet F (2006) Creep and time-dependent damage in argillaceous rocks. Int J Rock Mech Min Sci 43(6):950-960

Farmer I (1983) Engineering behaviour of rocks, 2nd edn. Chapman and Hall, London

Hagros A, Johanson E, Hudson JA (2008) Time dependency in the mechanical properties of crystalline rocks: a literature survey. Possiva OY, Finland

Hallbauer DK, Wagner H, Cook NGW (1973) Some observations concerning the microscopic and mechanical behaviour of quartzite specimens in stiff, triaxial compression tests. Int $\mathrm{J}$ Rock Mech Min Sci Geomech Abstr 10:713-726

Hoek E, Brown ET (1980) Empirical strength criterion for rock masses. J Geotech Eng Div, ASCE, 106(GT9):1013-1035

Hondros G (1959) The evaluation of Poisson's ratio and the modulus of materials of low tensile resistance by the Brazilian (indirect tensile) tests with particular reference to concrete. Aust J Appl Sci 10:243-268

Hunsche U (1992) True triaxial failure tests on cubic rock salt samples-experimental methods and results. In: Proceedings of IUTAM symposium on finite inelastic deformations-theory and applications, Hannover, Springer, pp 525-538

Hunsche U, Hampel A (1999) Rock salt-the mechanical properties of the host rock material for a radioactive waste repository. Eng Geol 52:271-291

Ishizuka Y, Koyama H, Komura S (1993) Effect of strain rate on strength and frequency dependence of fatigue failure of rocks. In: Proceedings of assessment and prevention of failure phenomena in rock engineering, pp 321-327

ISRM (2007) The complete ISRM suggested methods for rock characterization, testing and monitoring: 1974-2006. In: Ulusay R, Hudson JA (eds) Suggested methods prepared by the commission on testing methods, international society for rock mechanics, compilation arranged by the ISRM Turkish National Group, Ankara, Turkey

Ito H (1991) On rheological behaviour of in situ rock based on longterm creep experiments. In: Proceedings of 7th ISRM congress, Aachen, Germany, vol 1, pp 265-268

Ito T, Akagi T (2001) Methods to predict the time of creep failure. In: Proceedings of the 31 st symposium on rock mechanics of Japan, pp 77-81 (in Japanese)

Ito H, Sasajima S (1980) Long-term creep experiment on some rocks observed over three years. Tectonophysics 62(3-4):219-232

Ito H, Sasajima S (1987) A ten year creep experiment on small rock specimens. Int J Rock Mech Min Sci Geomech Abstr 24:113-121

Ito T, Fujiwara T, Akagi T (1999) Triaxial creep characteristics of soft rocks. In: Proceedings of the 29th symposium on rock mechanics of Japan, pp 126-130 (in Japanese)

Ito T, Aydan Ö, Ulusay R, Kaşmer Ö (2008) Creep characteristics of tuff in the vicinity of Zelve antique settlement in Cappadocia region of Turkey. In: Proceedings of 5th Asian Rock Mechanics Symposium (ARMS5), Tehran, pp 337-344

Jaeger JC, Cook NGW (1979) Fundamentals of rock mechanics, 3rd edn. Chapman \& Hall, London, pp 79 and 311

Kawakita M, Sato K, Kinoshita S (1981) The dynamic fracture properties of rocks under confining pressure. Mem Fac Eng Hokkaido University 15(4):467-478

Ladanyi B (1974) Use of the long-term strength concept in the determination of ground pressure on tunnel linings. In: Proceedings of 3rd congress, international society for rock mechanics, Denver, vol. 2B, pp 1150-1165

Ladanyi B (1993) Time-dependent response of rock around tunnels. In: Fairhurst $\mathrm{C}$ (ed). Comprehensive rock engineering: principles, practice and projects, vol 2, Analysis and design methods. Pergamon, Oxford, pp 77-112 
Lockner DA, Byerlee JD (1977) Acoustic emission and creep in rock at high confining pressure and differential stress. Bull Seismol Soc Am 67:247-258

Masuda K, Mizutani H, Yamada I (1987) Experimental study of strain-rate dependence and pressure dependence of failure properties of granite. J Phys Earth 35:37-66

Masuda K, Mizutani H, Yamada I, Imanishi Y (1988) Effects of water on time-dependent behavior of granite. J Phys Earth 36:291-313

Mirza UA (1978) Investigation into the design criteria for undergound openings in rocks which exhibit rheological behaviour. $\mathrm{PhD}$ thesis, University of Newcastle upon Tyne

Mottahed P, Szeki A (1982) The collapse of room and pillar workings in a shaley gypsum mine due to dynamic loading symposium on strata mech. Newcastle, pp 260-264

Okada T (2005) Mechanical properties of sedimentary soft rock at high temperatures (part 1) evaluation of temperature dependency based on triaxial compression test. Chiba, Japan: Central Research Institute of Electric Power Industry 04026, pp 1-26 (in Japanese)

Okada T (2006) Mechanical properties of sedimentary soft rock at high temperatures (part 2) - evaluation of temperature dependency of creep behavior based on unconfined compression test. Central Research Institute of Electric Power Industry, Chiba, Japan 05057, pp 1-26 (in Japanese)

Okubo S, Nishimatsu Y, Fukui K (1991) Complete creep curves under uniaxial compression. Int J Rock Mech Min Sci Geomech Abstr 28:77-82

Okubo S, Fukui K, Nishimatsu Y (1993) Control performance of servocontrolled testing machines in compression and creep tests. Int J Rock Mech Min Sci Geomech Abstr 30:247-255
Owen DRJ, Hinton E (1980) Finite element in plasticity: theory and practice. Pineridge Press Ltd, Swansea

Passaris EKS (1979) The rheological behaviour of rocksalt as determined in an in situ pressurized test cavity. Fourth International Congress on Rock Mechanics, Balkema, Rotterdam, pp 257-264

Peng S (1973) Time-dependent aspects of rock behavior as measured by a servo-controlled hydraulic testing machine. Int J Rock Mech Min Sci Geomech Abstr 10:235-246

Perzyna P (1966) Fundamental problems in viscoplasticity. Adv Appl Mech 9(2):244-368

Serata S, Sakurai S, Adachi T (1968) Theory of aggregate rock behavior based on absolute three-dimensional testing (ATT) of rock salt. In: Proceedings of 10th symposium on rock mechanics, University of Texas at Austin, pp 431-473

Shibata K, Tani K, Okada T (2007) Creep behaviour of tuffaceous rock under high temperature observed in uniaxial compression test. Soil Found 47(1):1-10

Slizowski J, Lankof L (2003) Salt-mudstones and rock-salt suitabilities for radioactive-waste storage systems: rheological properties. Appl Energy 75(1/2):137-144

Ulusay R, Ito T, Akagi T, Seiki T, Yüzer E, Aydan Ö (1999) Long term mechanical characteristics of Cappadocia tuff. The 9th international rock mechanics congress, Paris, pp 687-690

Wawersik WR (1983) Determination of steady state creep rates an activation parameters for rock salt. In: High pressure testing of rock, special technical publication of ASTM, STP86972-91

Yang CH, Daemen JJK, Yin JH (1999) Experimental investigation of creep behavior of salt rock. Int $J$ Rock Mech Min Sci 36(2):233-242 